\title{
On the Seedling.Structure of certain Piperales.
}

\author{
BY \\ T. G. HILL, F.L.S. \\ Lecturer on Biology in the Medisal School of St. Thomas's Hospital, London.
}

\section{With Plate $X$ and three Diagrams in the Text.}

THE completion of the investigation, started some time ago ${ }^{1}$, on 1 the structure of the seedlings of certain Piperales, has been much handicapped by the difficulty experienced in obtaining seeds; and the failure, in many cases, of these, when procured, to germinate. However, sufficient material has now been examined to warrant publication.

The cohort Piperales is of interest, inasmuch as it is characterized by certain features shared in common with many Monocotyledons. Thus Campbell ${ }^{2}$, comparing certain Araceae with Peperomia, remarks, 'in the form of the leaves and inflorescence, as well as in certain anatomical characters, e.g. the distribution of the vascular bundles in the stem of Peperomia, there are very curious parallelisms. The structure of the flower and position of the ovule are also similar.'

In a later paper ${ }^{3}$ he further expresses his opinion that 'the resemblances in general habit, as well as the distribution of the vascular bundles in Peperomia and the Araceae, might indicate a remote relationship between them; the presence in the latter of nucellar tissue, which might be compared to the perisperm of the Piperaceae, might be cited as further evidence of a possible relationship.... The possibility of a connexion with some of the lower Dicotyledons through forms like Peperomia may fairly be considered worthy of consideration.'

And further, in writing of Peperomia ${ }^{4}$, our author makes the following statement: 'From a study of many low types among the Monocotyledons, which cannot be readily derived from higher types, e.g. Naias, many Araceae, it seems more reasonable to consider the single carpel with

1 Hill, T. G. New Phytologist, Vol. iii, February, 1904.

2 Campbell, D. H. Studies on the Araceae, I. Ann. Bot., xiv, I900, p. 22. Studies on the Araceae, III. Ann. Bot., xix, I905.

The Embryo-sac of Peperomia. Ann. Bot., xv, I 901 .

[Annals of Botany, Vo1. XX. No. LXXVIII. April, 1906.] 
162 Hill.-On the Seedling-Structure of certain Piperales.

a single axial ovule as the primitive type for the Angiosperms, and with this Peperomia agrees perfectly.'

Thus it is obvious that in the light of recent research, more especially as regards questions dealing with the Phylogeny of the Angiosperms, the plants herein dealt with are of some importance.

\section{Piperaceae.}

Piper cornifolium, H. B.K. The basal region of each seed-leaf possesses one comparatively large collateral vascular bundle (Fig. I) which enters the petiole, when almost immediately a redistribution of the constituent tissues gradually takes place. The phloem is resolved into two masses, bounding the xylem on either side, and, at the same time,

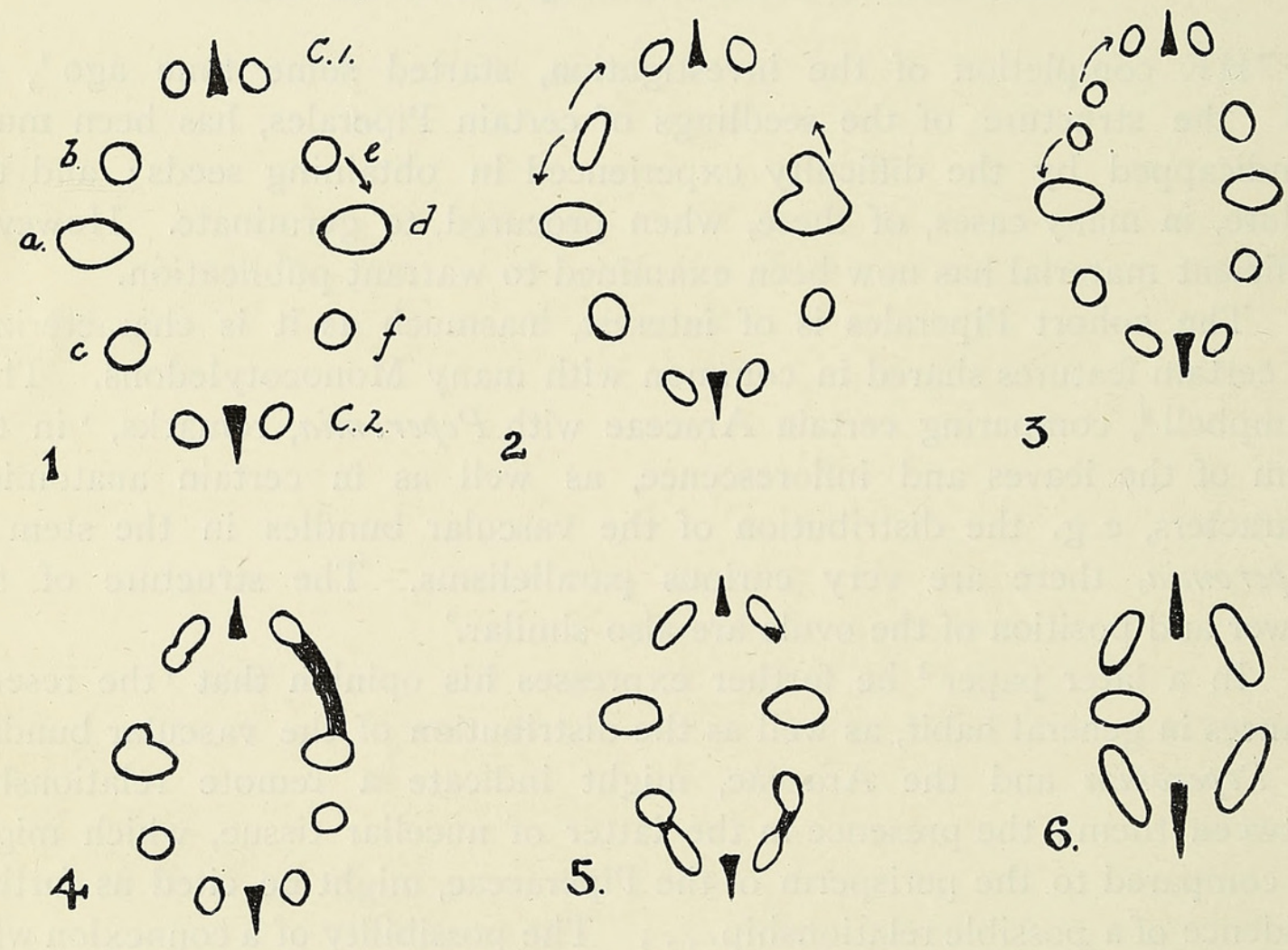

Diagram I.

Illustrating the anastomoses which occur between the phloem of the cotyledon bundles $C$. I, C. 2 , and the epicotyledonary strands $a, b, c, d, e$, and $f$. In the cotyledon-traces the exarch protoxylem is bounded on each side by a group of phloem elements.

the xylem undergoes rotation, so that the protoxylem becomes exarch, whilst the bundle is still within the petiole of the cotyledon (Figs. 2 and 3). At the cotyledonary node the bundles enter the axis and pass towards the centre, which, in the oldest seedling examined, possessed six bundles derived from the plumule. These epicotyledonary traces exercise no influence on the transition phenomena, and were, for the most part, still merismatic, one only containing lignified elements. They are arranged in 
two groups, each consisting of three strands, the largest bundles occupying a central position in their respective group. Anastomoses take place between these plumular traces and the two phloem masses of each cotyledon-bundle, the exact junctions being illustrated in the accompanying Diagram I, from which it will be seen that, essentially, the lateral bundles, $b, c, e$, and $f$, fuse with the nearest cotyledonary phloem mass, and then the four phloem groups thus formed take up a more central position, the neighbouring phloems joining up to form two groups. The protoxylem is already exarch, and occupies its proper position relative to the bast; thus a typical diarch root obtains (Figs. 4, 5, and 6, Plate X).

It has already been pointed out by Tansley and Thomas ${ }^{1}$ that this is an extreme case of what obtains in other plants. They themselves 'have found this type in fourteen genera of Ranunculaceae, in certain Berberidaceae, and in every genus examined (twenty-four in all) belonging to the orders Papaveraceae (including Fumariaceae), Capparidaceae, Resedaceae, and Cruciferae'. Sterckx ${ }^{2}$, Gérard ${ }^{3}$, Miss Sargant ${ }^{4}$, and Tansley $^{5}$ have described the same type as occurring in certain Ranunculaceae and allied plants; Miss Sargant ${ }^{4}$ and Chauveaud ${ }^{6}$ have drawn attention to the presence of a similar type in a number of monocotyledonous plants, and, finally, the writer has found it to obtain in certain Centrospermae. Further research will show whether the type is of more general occurrence throughout the Dicotyledons.

One of the seedlings examined possessed three cotyledons, the plumule was in an embryonic state, and its vascular bundles were much less developed than in the plant just described.

The transition in this tricotyledonary specimen followed precisely similar lines to those described for the normal plant. At the cotyledonary node each bundle with its bifurcated phloem and exarch protoxylem passes inwards, and, as they do so, the phloem groups of each bundle separate more and more, until each ultimately comes into contact with a phloem group of one of the other cotyledonary traces, so that finally three phloems result. The xylem strands converge towards the centre of the

1 Tansley, A. G. and Thomas, E. N. Root Structure in the Central Cylinder of the Hypocotyl. New Phytologist, Vol. iii, No. 4, April, 1904.

2 Sterckx. Recherches anatomiques sur l'embryon et les plantules dans la famille des Renonculacées. Mem. Soc. Roy. Sci. Liège, sér. 3, t. ii, I899.

3 Gérard, R. Recherches sur le passage de la Racine à la Tige. Ann. Sci. Nat. Bot. sér. 6, t. xi, I 880 .

4 Sargant, E. A Theory of the Origin of Monocotyledons founded on the Structure of their Seedlings. Ann. Bot., xvii, I903.

5 Tansley, A. G. Reduction in Descent. New Phytologist, Vol. i, I902.

- Chauveaud, M. G. Passage de la position alterne à la position superposée de l'appareil conducteur, avec destruction des vaisseaux centripètes primitifs, dans le cotylédon de l'Oignon (Allium Cepa). Bull. du Mus. d'Hist. Nat., No. I, I902, p. $5^{2}$.

Chauveaud, M. G. Sur le passage de la disposition alterne des éléments libériens et ligneux à leur disposition superposée dans le Trocart (Triglochin). Bull. du Mus. d'Hist. Nat., No. 3, 1901, p. I 24 . 
axis in a straight line, and obviously occupy positions between the phloem masses: thus a triarch root is produced. These changes do not end here: normally, of course, two seed-leaves are present, and the root is diarch ; in this case there are three cotyledons, and the root is triarch.

On the examination of the root at a lower level it is seen that the triarch structure becomes diarch. The changes leading to the alteration are illustrated in Diagram II.
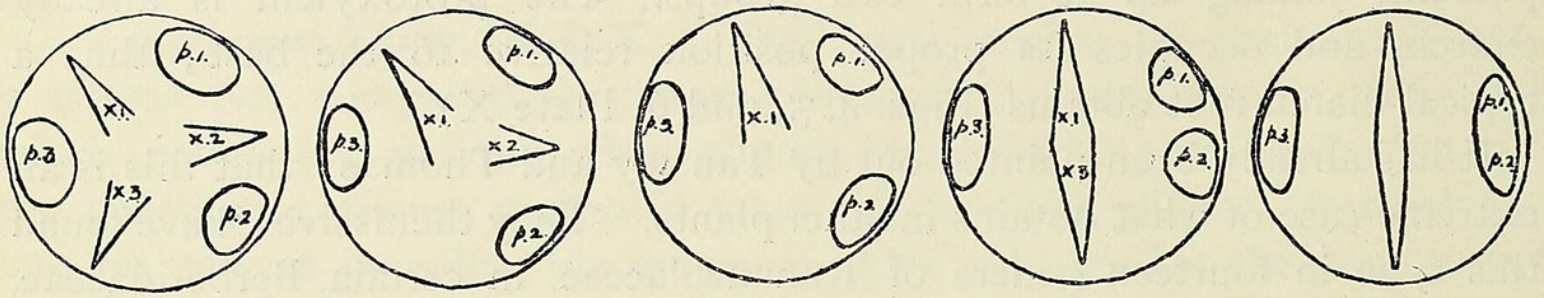

DIAGRAM II.

Terming the xylem and phloem groups $X . \mathrm{I}, X .2, X .3, p . \mathrm{I}, p .2$, and $p .3$, respectively; one xylem mass, $X .3$, temporarily disappears, and this is followed by the obliteration of the group $X .2$. So that, at this stage, there obtains, as regards the xylem, a monarch structure. The phloems $p$. I, $p .2$ now approach one another to form a single strand, and, at the same time, the xylem ray, which was the first to disappear, reappears. Thus there results a diarch root.

Piper geniculatum, Hort. ex Link., follows a precisely similar course, even to the behaviour of the epicotyledonary traces.

Peperomia eburnea, Linden. At the distal end of the petiole of each cotyledon the bundles of the blade fuse together to form a single strand, the behaviour of which is not necessarily the same in each petiole. In one seedling it was found that in one petiole there was a normal collateral bundle with endarch protoxylem; tracing this strand downwards, no bifurcation of the phloem occurs, but the strand, as a whole, becomes somewhat obliquely orientated with the greater mass of phloem on one side, and also with the smallest xylem element somewhat more exarch than its neighbours. Immediately above the cotyledonary node this bundle shows its xylem tangentially arranged, and its phloem in an early stage of bifurcation.

Turning now to the other cotyledon, the bundle is found, at the distal end of the petiole, to be somewhat $U$-shaped, the xylem forming a tangential row of elements between the two groups of phloem elements. At a lower level, the xylem of this strand undergoes rotation, so that by the time the node is reached the bundle has its protoxylem exarch and its phloem in two masses. These differences will be realized by the examination of Figs. 7, 8, and 9, of which the two first illustrate the appearance of the two bundles at the same level. As the cotyledonary traces pass inwards towards the centre of the axis, the phloem of the bundle first described separates into two well-defined masses, corresponding to what obtains in the other. The course now followed is the same as in Piper, except that as regards the bundle first described no rotation of the xylem 
could be made out; if it takes place, it must do so during its inward passage from the node, but what probably occurs is that the metaxylem elements overtake and pass the protoxylem, so that the latter become exarch. A diarch root-structure is thus formed directly the two strands meet in the centre of the axis.

Other seedlings showed what is probably the normal course, viz. each endarch bundle of the cotyledon petiole, as it passes downwards towards the node, exhibits a bifurcation of the phloem and a rotation of the xylem as described for Piper, but this rearrangement in Peperomia eburnea is not nearly so decided as in Piper.

A further anomaly was exhibited by another seedling of this same species; the cotyledonary bundles showed the normal rearrangement, but one also possessed a group of phloem elements on the protoxylem side of the strand. This extra phloem decreased in amount, so that by the time the centre of the axis was reached it consisted of but a few elements which still retained their abnormal position internal to the protoxylem. Ultimately they entirely disappeared.

This same specimen was also peculiar, inasmuch as a normal rootstructure took much longer to form than in other individuals of the same species.

Peperomia pellucida, H. B. K. One vascular bundle enters the distal end of each petiole from the cotyledon (Fig. I3). Tracing the strand downwards, the phloem gradually forms two groups of elements as in Pep. eburnea, but frequently this bifurcation is not equally well marked in the bundle of each seed-leaf petiole. Immediately before the node is reached there is a suggestion of the protoxylem taking up an exarch position.

The cotyledonary traces pass inwards as relatively broad bands; the phloem groups of each strand separate and pass to opposite sides of the central cylinder, where they come into contact with the plumular bundles which, in the youngest seedling examined, were still in a procambial state and arranged in two groups, one on each side of the central cylinder, and separated by parenchymatous elements. Thus the two phloems of the root result.

Concurrently, the xylem follows a centripetal course, the metaxylem travels further inwards, thus leaving the protoxylem in an exarch position; these elements are very few in number, there being one on one side and two on the other. The tracheae are irregularly disposed, and there is no diarch plate such as obtains in Piper, at about this stage (Fig. I4).

Following these structures downwards, new xylem elements may make their appearance external to, and in contact with, the existing protoxylem. Further, it is seen that these elements follow an undulating course, so that in one transverse section they may be in contact with the metaxylem 
tracheae, and at a lower level they may be separated from them by two or three parenchyma cells. Finally, however, the two protoxylem groups come into contact with the metaxylem elements, which range themselves in line, so that a typical diarch plate obtains.

In older seedlings the epicotyledonary axis has six bundles, three derived from each of the two foliage leaves, arranged roughly in a circle. Much anastomosing and redistribution take place between these traces, as a result of which there are formed two strands, separated one from the other by parenchyma, and situated at right angles to the line joining the two cotyledonary bundles. As soon as this arrangement is effected the seedleaf traces enter the central cylinder in the manner already described.

In these older seedlings more metaxylem is derived from the plumule than from the cotyledons, but these elements rapidly disappear, so that at the slightly lower level the lignified elements obtaining are those derived from the seed-leaves.

Peperomia polystachya, Hook. The material of this plant was not entirely satisfactory, inasmuch as very few of the seedlings retained their cotyledons. Thus it was not possible to follow the course of the bundle from the cotyledon to the petiole. Sufficient, however, was made out to indicate that, as regards the behaviour of the bundles of the seed-leaves, this species occupies a position intermediate between Pep. pellucida and Pep. amplexifolia. At the base of the petiole of each seed-leaf a single strand may be seen with its protoxylem in an endarch position, and its phloem spread out tangentially and somewhat bilobed.

Immediately before its entry into the axis the metaxylem may be seen to be separated into two masses by parenchyma, but no rotation of the protoxylem can be made out.

When the plumule is well developed the bundles of the third internode are markedly arranged in two whorls, six strands in the outer, and four in the inner. At the node below the incoming traces fuse with certain of these bundles, and anastomoses occur between the vascular strands of the two whorls, so that in the second internode there obtain three bundles in the inner and six in the outer ring. Similar junctions take place at the node below, resulting in the formation of a single strand centrally placed and surrounded by a zone of five. These bundles join up with one another, hence there result four epicotyledonary strands, two on one side and a similar pair on the opposite side of an imaginary line joining the two incoming cotyledonary traces.

As the seed-leaf bundles approach the centre of the axis the phloem of each separates into two masses which fuse with the phloem of the nearest plumular trace. This branching of the cotyledonary bast is sometimes very unequal, for nearly all the phloem from one bundle may go to one of the pair of plumular bundles. 
The xylem, small in amount, of the seed-leaves pursues a straight course, and comes into contact with the protoxylem of the plumular strands, the two then being practically indistinguishable.

The four epicotyledonary bundles fuse in pairs, to form two large pyriform strands. Lower down, the central cylinder loses its oval shape and becomes rounded in outline. At the same time the metaxylem becomes less abundant, and, at a still lower level, the central xylem gradually takes up a position nearer the endodermis; the smallest elements, however, do not occupy an exarch position. Thus a really typical root-structure does not obtain; the plant under consideration resembling, in this respect, Pep. maculosa and Pep. tithymaloides.

Peperomia amplexifolia, A. Dietr. The petiole of each seed-leaf has the usual single bundle. These strands are small as viewed in transverse sections, each being no larger than one of the surrounding parenchyma cells. No bifurcation of the phloem nor rotation of the xylem takes place, as in the plants hitherto described. The cotyledonary traces enter the axis as normal collateral structures. In one plant it was noticed that at the base of the seed-leaf petiole the strands were placed obliquely to the dorsoventral line of the cotyledon; but this did not obtain in the other individuals examined.

Another feature of interest is the fact that the free edges of the bases of the petioles of the seed-leaves fuse, so that there is formed a cotyledonary tube around the axis.

The oldest seedling examined possessed two young foliage leaves, each having three bundles, one large and central, with lignified elements, and two smaller, lateral in position, and more or less merismatic.

The traces of the youngest leaf enter the axis and fuse with the merismatic central cylinder. At a slightly lower level the bundles of the leaf are seen alternating with three small merismatic strands, which are situated nearer the centre. At the node next below the bundles of the oldest leaf enter, so that there result two well-marked zones of bundles. Those of the oldest leaf move centripetally, so that at the cotyledonary node the strands no longer exhibit a scattered disposition. Fusions now take place between the various plumular traces, as a result of which four vascular strands are formed. During these changes the cotyledonary bundles have entered the axis, and occupy a position one on each side of the group of plumular traces. One cotyledon-trace fuses with the nearest epicotyl-bundle; the metaxylem and phloem of both coming into contact, and the protoxylem of the seed-leaf being somewhat isolated. Further junctions take place between the plumular traces, so that two large bundles result. The other cotyledon-trace now fuses up, its phloem dividing into two unequal strands, the largest of which joins with the bast of the bundle alternate to that with which the first cotyledon-trace fused, 
I68 Hill.-On the Seedling-Structure of certain Piperales.

and the protoxylem occupying a position corresponding with that taken up by the same tissue of the opposite seed-leaf. As soon as these changes (the details of which are figured in Diagram III) have been effected, an endodermis puts in an appearance, and the central strand has a typical root-like appearance.

The fact that the two cotyledon-bundles fused with the plumular

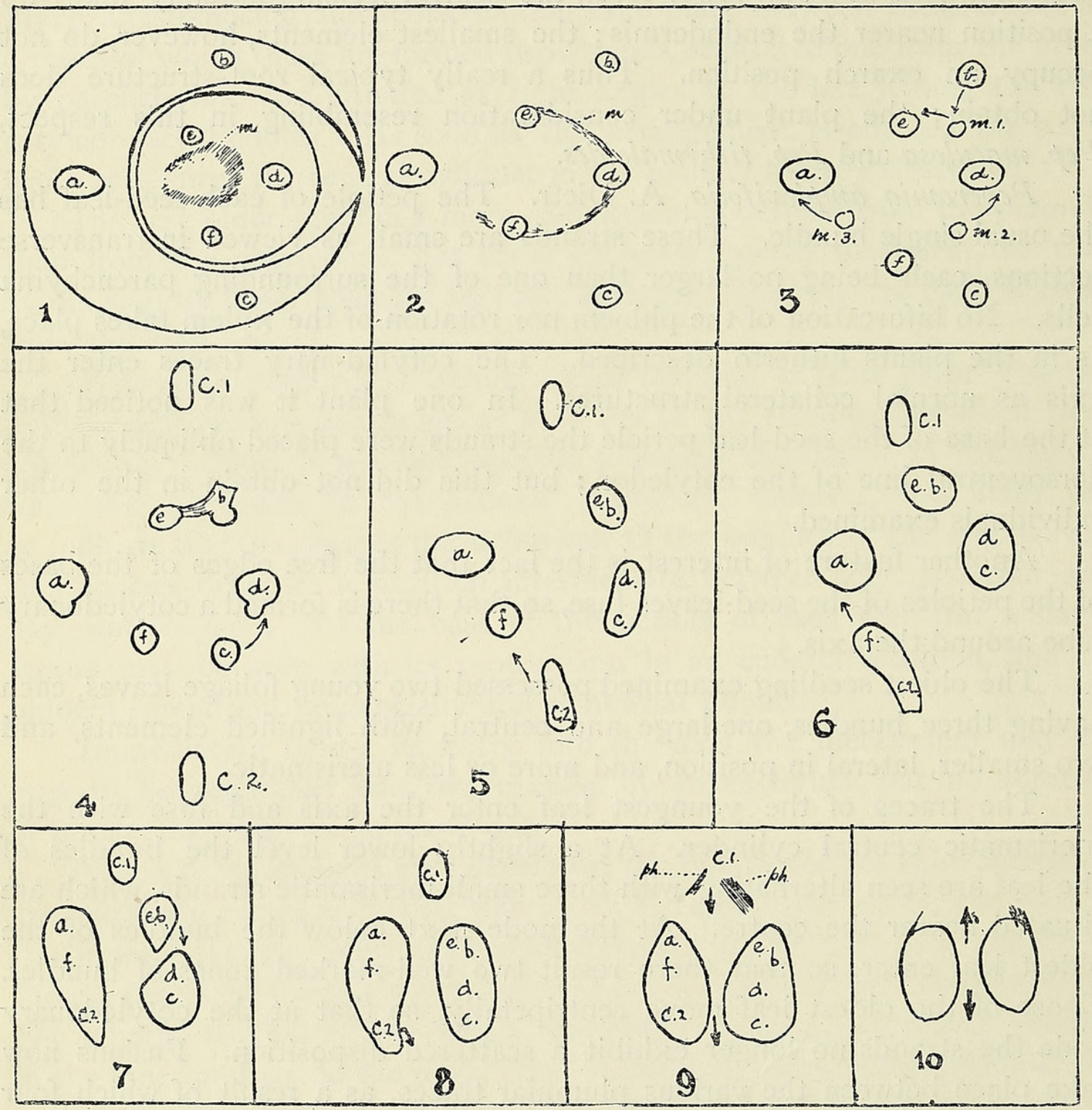

DIAGRAM III.

$a, b, c, d, e, f$, plumular bundles ; $m$, merismatic tissue ; $m$. I., m. 2., m., 3., merismatic bundles ; C. I., C. 2., cotyledon-traces; $p h .$, phloem. The heavy arrows indicate the protoxylem of the cotyledon-traces.

traces at slightly different levels is probably to be accounted for by the cotyledons themselves being inserted at slightly different levels.

There is no definite rotation of the protoxylem elements; they seemingly occupy their exarch position owing to the fact that the metaxylem moves away from and leaves them isolated, a reunion being afterwards effected. 
On comparing these changes with those obtaining in Arum maculatum $^{1}$, many points of similarity are to be found, more especially as regards the zoning and fusions of the plumular traces, and the method of union of the cotyledon-bundles with these strands. But, at the same time, it must be pointed out that a certain amount of variation obtains in Pep. amplexifolia: thus, in a seedling of about the same age as the one just described, it was found that, although the youngest foliage leaf contributed the normal number three, only one bundle entered the axis from the oldest foliage leaf, so that instead of having two zones of bundles the axis had an irregular ring of four strands.

At a level slightly below the cotyledonary node intercommunications take place between the plumular traces, resulting in the formation of two bundles somewhat obliquely situated, and with their xylems separated by a thin layer of parenchyma. This arrangement is effected immediately before the entry and fusion of the cotyledonary traces, which enter the axis and travel to the central vascular strand as collateral structures. Immediately before fusion the phloem of each branches to the right and left of the xylem, and comes into contact with the bast of the epicotyl-bundles, while the xylem behaves in the manner already described.

Both in this and in other species it is sometimes found that the phloem of the cotyledonary traces divides into two very unequal strands, so that one side of the vascular cylinder may sometimes receive nearly the whole of the phloem of one seed-leaf bundle.

Peperomia tithymaloides, A. Dietr. All the seedlings examined had a well-formed plumule with three foliage leaves. The structure of the epicotyl is similar to that of Pep: amplexifolia, as regards the definite zoning of the bundles, and the anastomosing of these structures at the nodes. The chief difference lies in the fact that the number of the leaf traces is rather more variable in Pep. tithymaloides. Thus, in one plant, the youngest leaf had four traces, the next youngest three, and the oldest only one; three strands, however, appear to be the typical number.

The cotyledonary bundles are small, single, and collateral (Fig. 10); and, as in Pep. amplexifolia, and the species described hereafter, there is no bifurcation of the phloem, nor rotation of the xylem. Immediately before the entry of the seed-leaf traces the plumular strands are arranged in an elliptical zone, three being on one side and three on the opposite side, the largest of each group being bounded by the smaller. The cotyledonary bundles enter and occupy positions corresponding to the foci of the ellipse. The phloem of these branches to the right and left of the xylem, and, passing inwards, fuses with the corresponding tissue of the plumular strands, while the metaxylem travels towards the centre and effects a junction with 
the xylem of the plumular bundles, thus forming a somewhat irregular plate. Concurrently, the three epicotyledonary bundles of each side fuse, so that there result two large collateral structures, one on each side. The two protoxylem groups derived from the cotyledons retain their relative and isolated position for some time, having a crushed appearance, some being almost entirely obliterated (Fig. JI). Ultimately, these protoxylem groups come into contact with the xylem of the plumular strands; at a still lower level an endodermis is differentiated, and the vascular tissue decreases in amount (Fig. I2).

Peperomia maculosa, Hook. The transition phenomena are essentially the same as in the last species dealt with. The differences which obtain are unimportant, and are briefly as follows. At the level of the insertion of the seed-leaves the epicotyledonary strands are five in number, three in one group and two forming the corresponding opposite group; whereas in Pep. tithymaloides there are six bundles arranged in threes. Further, the phloem of the seed-leaf traces branches somewhat earlier in Pep. maculosa. And again, in the last-named plant, all the xylem, with the exception of one element of the cotyledonary strands, passes to the centre of the vascular cylinder, fusing one with the other and with the wood of the plumular bundles, which, by this time, have formed two large pear-shaped structures. The elements left behind occupy a solitary position well towards the periphery of the stele, one on each side, and they independently follow an undulating course downwards; so that a diarch plate, small and not well defined, may result at one level, while at a lower level the plate may exist on one side and not on the other.

One seedling exhibited a curious anomaly, which resulted in a seemingly unnecessary redistribution of vascular tissue.

Towards the base of the axis a strand of phloem was given off from one of the phloem masses of the central cylinder. The strand followed a downward spiral course, passing on the outside of the protoxylem, and receiving elements from the metaxylem in its passage, thus appearing as a collateral structure, but quickly becoming somewhat more root-like by a rearrangement of the phloem; but instead of emerging as a lateral root it pursued its spiral course, circling around to the side from whence it came, and ultimately fused with the vascular cylinder.

It may be added that a lateral root does, in this species and in others, sometimes arise directly opposite a phloem group.

From the foregoing account it is clear that the species of Peperomia examined fall into two divisions. In the first may be placed $P e p$. eburnea and Pep. pellucida, both characterized by the occurrence of a certain amount of rearrangement in the cotyledonary bundles, while still contained within the petiole; and in the second, Pep. polystachya, Pep. 
amplexifolia, Pep. tithymaloides, and Pep. maculosa, in which. no such rearrangement takes place. These two groups merge imperceptibly one into the other; and further, a gradual reduction in the transition phenomena may be traced from Piper cornifolium, which forms one extreme, to Peperomia tithymaloides, which forms the other extreme. In the first case the vascular tissue of the root is derived chiefly from the cotyledons, while in the last the seed-leaf traces are unimportant; the plumular bundles playing the prominent part.

The absence of rotation in the xylem of the seed-leaf bundles is seemingly not confined to Peperomia. Chauveaud ${ }^{1}$ has described what appears to be a similar case in the Labiatae. He remarks : 'Dans le Lamium album ... les deux faisceaux ligneux primaires de la radicule se continuent jusque dans les cotylédons, en demeurant toujours dans le même plan, qui est le plan de symétrie des cotylédons. Ces faisceaux ne se partagent pas en deux masses et aucune rotation n'intervient.'

\section{SAURURACEAE.}

Houttuynia cordata, Thunb. The transition phenomena are similar to those already described for Peperomia. The petioles of the seed-leaves form a short tube round the axis ; each contains one bundle, which, throughout its course, remains collateral with its protoxylem endarch in position. These bundles have their xylem but feebly developed, there being not more than two or three elements in each strand. On arriving near the centre of the axis the phloem branches to the right and left of the xylem, the corresponding groups fusing to form the two phloem masses of the roots. Concurrently, during the inward passage there is seemingly a rearrangement of the xylem, which results in the smallest elements being exarch in position. Metaxylem appears; a root-structure with a typical diarch plate results (Figs. 16 and 17 ).

In older seedlings the cotyledonary tube is better marked, and their bundles have more xylem (Fig. I5).

The plumular traces fuse together, forming two fairly large collateral bundles occupying the centre of the axis, one on each side. As in Pep. polystachya and Pep. amplexifolia, the bifurcation of the cotyledonary phloem is very unequal, sometimes almost non-existent, inasmuch as practically the whole of this tissue from one seed-leaf bundle may fuse with the bast of one of the two plumular strands. This inequality of distribution is most marked in the older seedlings, and the reason for its occurrence may be to render each phloem group of the root equal in size.

The xylem of the cotyledon-bundles of the older seedlings behaves in the manner already described: there is, however, a certain amount of

1 Chauveaud, M. G. Sur la persistance de la structure alterne dans les cotylédons du Lamier blanc et de plusieurs autres Labiées. Comptes Rendus, 2 I mars 1904. 
variation. The protoxylem may become exarch during the inward passage; sometimes the final disposition is reached by the dying out of the accompanying metaxylem. Further, in one case, it was observed that the cotyledonary xylem enters the central cylinder as an endarch mass, the exarch position of the protoxylem being arrived at by the metaxylem bending roun and taking up a morecentral position.

The transition takes place very quickly, and an endodermis makes its appearance directly it is accomplished.

Saururus cermus, Linn. The petioles of the cotyledons form a tube round the axis as in $H$. cordata, and, as the transition phenomena are also identical with those of the latter, no detailed description is called for.

The only point to be remarked is that in one plant the phloem of the bundle of one cotyledon, not of the other, exhibited a bifurcation in the base of the petiole.

Houttuynia and Saumur thus resemble Peperomia, and they, together with Piper, on the whole, conform to Van Tieghem's type 3.

\section{THEORETICAL.}

The first question of theoretical interest is whether Peperomia is to be considered as a primitive or a reduced form. Campbell ${ }^{1}$ maintains that in Peperomia we have to deal with the most primitive type of Angiosperm yet discovered, and that the peculiarities of the embryo-sac are not reductions, but consist of an increase in the number of parts. On the other hand, Johnson ${ }^{2}$ in his work on the embryo-sac of Peperomia expresses himself as follows: "That these peculiarities are to be considered primitive rather than higher specializations seems to me unwarranted by the evidence at present available, especially when we consider the fact, which I have ascertained, that such closely related genera as Piper, Heckeria, and Saururus ${ }^{3}$ have essentially typical angiosperm embryosacs. ... I am inclined to believe that the peculiarities of the embryo-sac of Peperomia have been secondarily acquired, and are analogous to those found in other angiosperms of peculiar habit; e.g. many aquatic, parasitic, and saprophytic forms.'

Finally, Johnson ${ }^{4}$ has recently expressed the opinion that the development of the megasporangium and the female gametophyte of Angiosperms is an unsatisfactory index of genetic relationship, inasmuch as it may vary

${ }^{1}$ Campbell, D. H. Die Entwickelung des Embryosackes von Peperomia pellucida. Ber. d. deut. Bot. Gesells. xvii, I 899 .

Campbell, D. H. The Embryo-sac of Peperomia. Ann. Bot., xv, r 901.

2 Johnson, Duncan S. On the Endosperm and Embryo of Peperomia pellucida. Bot. Gaz., xxx, 1900.

3 Johnson, Duncan S. On the Development of Saururus cernuus. Torrey Bot. Club Bull., I900. See also On the Development of certain Piperaceae. Bot. Gaz., xxxiv, 1902 .

4 Johnson, Duncan S. Seed Development in the Piperales and its bearing on the Relationship of the Order. Johns Hopkins Univ. Circ. No. $178,1905$. 
considerably in the same family or genus. He also states his opinion that the Piperales are not very primitive, and that, in all probability, their nearest relations are to be found in those cohorts characterized by the presence of perisperm, viz. the Aristolochiales, Polygonales, Centrospermales, and the Ranales.

However this may be, and much may be said against the view here expressed, the facts relating to the structure of the seedlings strongly confirm Johnson's hypothesis ${ }^{1}$, and, without expressing an opinion upon the relative primitiveness of the order, the writer is in full accord with this view that Peperomia is a reduced genus. And this opinion is, in the case of Peperomia pellucida, much strengthened by the fact that 'the embryo remains very small and shows no differentiation when the seed is ripe', ${ }^{2}$ which, in the opinion of the present writer, more than counterbalances the increase in the number of the constituent parts in the embryo-sac.

If, then, Peperomia be a reduced form, what is the factor which has brought about the reduction?

Both Campbell ${ }^{3}$ and Johnson ${ }^{1}$ have apparently recognized what Tansley ${ }^{4}$ afterwards expressed, viz., that in the apparent absence of some cause to which the reduction may be ascribed, 'the hypotheses of relative primitiveness and of reduction do not stand on an equal footing. The former has the logically prior claim, and must be accepted as a working theory until good grounds can be given for preferring the latter.'

Johnson ${ }^{5}$ suggests that the peculiarities of Peperomia are analogous to those found in many aquatic, parasitic, and saprophytic Angiosperms; in reply to which, Campbell ${ }^{6}$ remarks that 'the habit of the plant in question conforms to neither of these forms, i. e. there is nothing to account for the reduction.'

The present writer suggests that the determining factor which has brought about the reduction may be found in the epiphytic habit of many of the forms.

The second feature of theoretical interest is the bearing of the facts described upon some of the current and possible hypotheses relating to the phylogeny of the Angiosperms. Briefly, these theories are as follows:-

I. The Dicotyledons have arisen from the Gymnosperms.

2. Of the Angiosperms, the Dicotyledons are the more ancient group, and have given origin, through the Ranunculaceae, to Monocotyledons.

3. The Monocotyledons have given rise to the Dicotyledons, the connexion being through the Araceae and the Piperaceae.

4. Further, if it be held that the single seed-leaf has been formed by

1 Bot. Gaz., xxx, I900.

2 Campbell. The Embryo-sac of Peperomia. Ann. Bot., xv, p. II2, I90I.

3 Loc. cit.

* Tansley, A. G. Reduction in Descent. New Phytologist, Vol. i, p. I 3 I, I902.

5 Loc. cit.

' Loc. cit. 


\section{I74 Hill.-On the Seedling-Structure of certain Piperales.}

the fusion of two cotyledons, then, bearing in mind the resemblances between the Ranunculaceae and certain Monocotyledons, and between the Piperaceae and the Araceae, it may be argued that the Monocotyledons are diphyletic.

We may, with Miss Sargant, consider that the transition phenomena of seedlings have a phylogenetic value; and it is clear that the type of transition herein described is not uncommon in Dicotyledons, so much so, indeed, that Tansley and Thomas ${ }^{1}$ remark that 'the importance of this simple and striking type of hypocotyledonary structure is sufficiently apparent from its uniformity in the orders named. The temptation to regard it as of phylogenetic importance in relation to the Dicotyledons as a whole, already strong in view of its occurrence in the almost certainly primitive Ranunculaceae and their allies, is increased by its discovery in the Piperaceae.' This temptation is doubtless strengthened by the occurrence of the type in the Labiatae and Centrospermae. Further, the work of Miss Sargant and Chauveaud shows that a similar type obtains in different orders of the Monocotyledons; Chauveaud ${ }^{2}$, in his work on Pinus maritima, has described features identical with some of those of this particular type as it occurs in Angiosperms. The differences which obtain may be looked upon as modifications due to the increased number of cotyledons in Pinus, and although our knowledge of the seedling anatomy of these plants is decidedly scanty, it is probable that this modified type occurs in other Gymnosperms. Thus the evidence afforded by transition phenomena, if a phylogenetic value be assigned to it, supports all the above contentions. Hence it does not appear, from the facts at our disposal, that this evidence helps in the slightest degree in the elucidation of the phylogeny of the Angiosperms.

But do the transition phenomena yield data of phylogenic importance? Further research will show; in the meantime, it may not be considered inappropriate to draw attention to a few points. Miss Sargant has shown that much variation obtains in this respect in the Liliaceae, a similar diversity has been found by Wright ${ }^{3}$ to obtain in different species of Diospyros, the present work shows that the details of the transition in the Piperaceae are anything but rigid, and, finally, the writer has found that there is seemingly much variation in the Centrospermae.

It will probably be agreed that features taken as indicating phylogeny should be sufficiently rigid to withstand the influence of varying conditions, both internal and external.

Is this the case in these transition phenomena?

1 Loc. cit., p. 106.

${ }^{2}$ Chauveaud, M. G. Passage de la disposition primitive à la disposition secondaire dans les cotylédons du Pin maritime (Pinus maritima). Bull. du Mus. d'Hist. Nat., I902, No. 7 .

3 Wright, H. The Genus Diospyros in Ceylon; its Morphology, Anatomy and Taxonomy. Ann. Roy. Bot. Gard. Peradeniya, ii, I904. 
Nothing has been said regarding the bearing of the geophilous habit exhibited by certain species of Peperomia; we shall be in a better position to discuss this when A. W. Hill ${ }^{3}$ has published a detailed account of the highly interesting plants discovered by him in the Andes.

To conclude, it may be stated that this work was commenced in the Jodrell Laboratory, Kew.

I desire to express my thanks to Dr. Scott for placing at my disposal material in his possession, and also to Mr. Hales, Curator of the Old Physic Garden, Chelsea, who not only obtained seeds for me, but also undertook their germination.

1 Hill, A. W. Note on some peculiar features in seedlings of Peperomia. Proc. Phil. Soc. Cambridge, Vol. xiii, Pt. i.

\title{
EXPLANATION OF PLATE $\mathrm{X}$.
}

\author{
Illustrating Mr. T. G. Hill's paper on the Piperales.
}

Abbreviations: c.ph., cotyledonary phloem; $c x$., cotyledonary xylem; end., endodermis ; $p h .$, phloem ; $p x$., protoxylem; $x_{\text {., }}$ xylem; T. S., transverse section.

Fig. I. Piper cornifolium T. S. of cotyledonary bundle at the top of the petiole.

Fig. 2. , , ,

Fig. 3. ", ,

Fig. 4. " "

Fig. 5. " " ,

Fig. 6. " " ,

Fig. 7. Peperomia eburnea.

Fig. 8. , , ,

Fig. 9. " ",

Fig. Io. Pep. tithymaloides.

Fig. 11. " " "

Fig. I 2. ", ",

Fig. I3. "pellucida.

Fig. 14. " " ,

Fig. 15. Houttuynia cordata.

Fig. 16. ," ,

Fig. 1\%. " , ,
The same bundle at a lower level.

The same immediately before entry into the axis.

T. S. hypocotyl before the fusion of the phloem masses.

The same after fusion of the phloem groups.

T. S. root.

T. S. of one cotyledonary bundle, showing slight bifurcation of the phloem.

T. S. of the other cotyledonary bundle, at the same level as in Fig. 7 .

Same bundle as in Fig. 8, but at a lower level.

T. S. cotyledonary bundle.

T. S. hypocotyl.

T. S. root.

T. S. cotyledonary bundle.

T. S. hypocotyl.

T. S. cotyledonary bundle.

T. S. hypocotyl, showing entry of cotyledon-traces.

T. S. root. 
Annals of Botany.

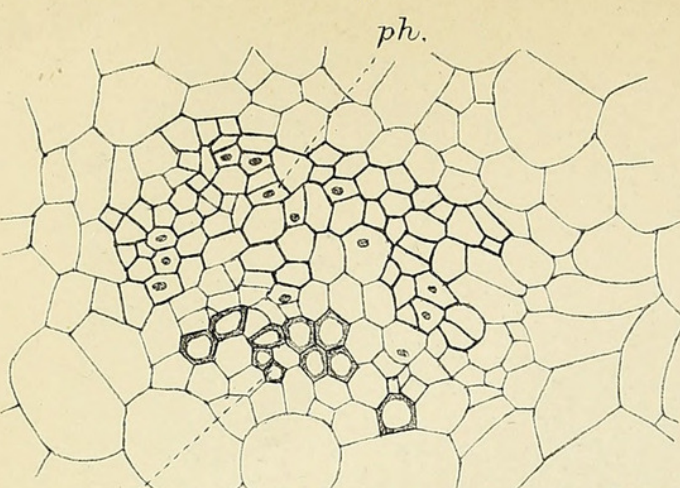

$1 \times 280$.

$p x$

$2 \times 280$.

pho px. ph.

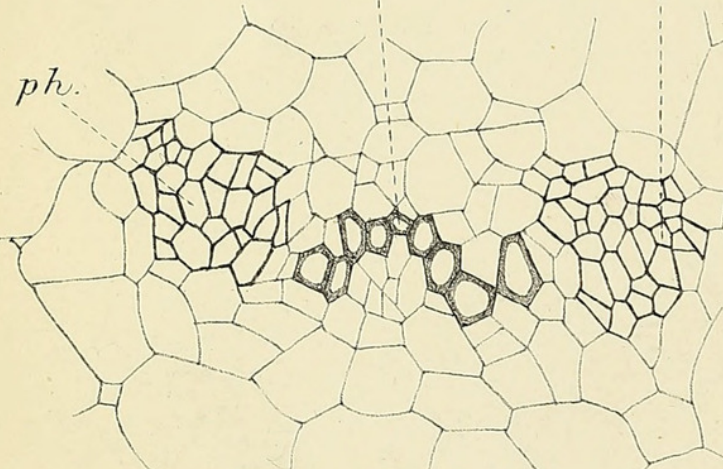

$3 \times 280$
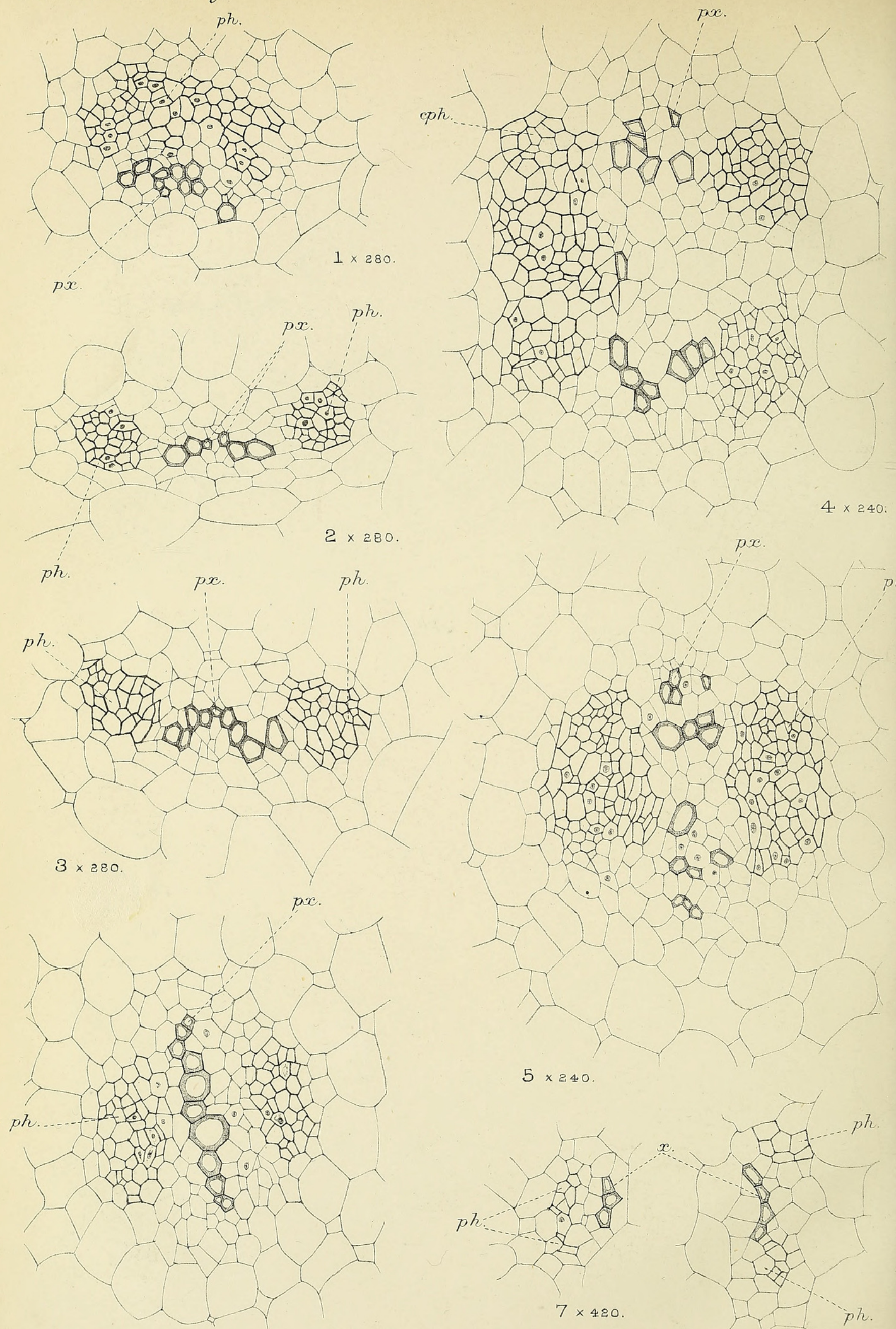

$6 \times 240$

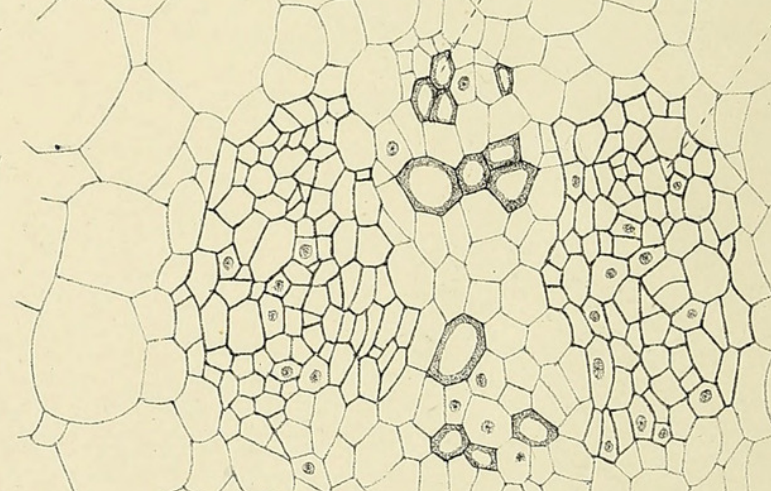

$5 \times 240$

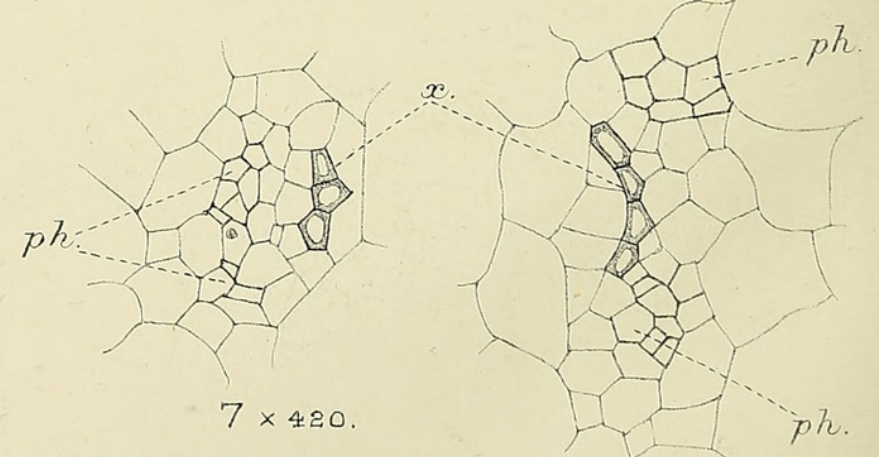

$8 \times 420$. 
Vol:XX,Pl.X.
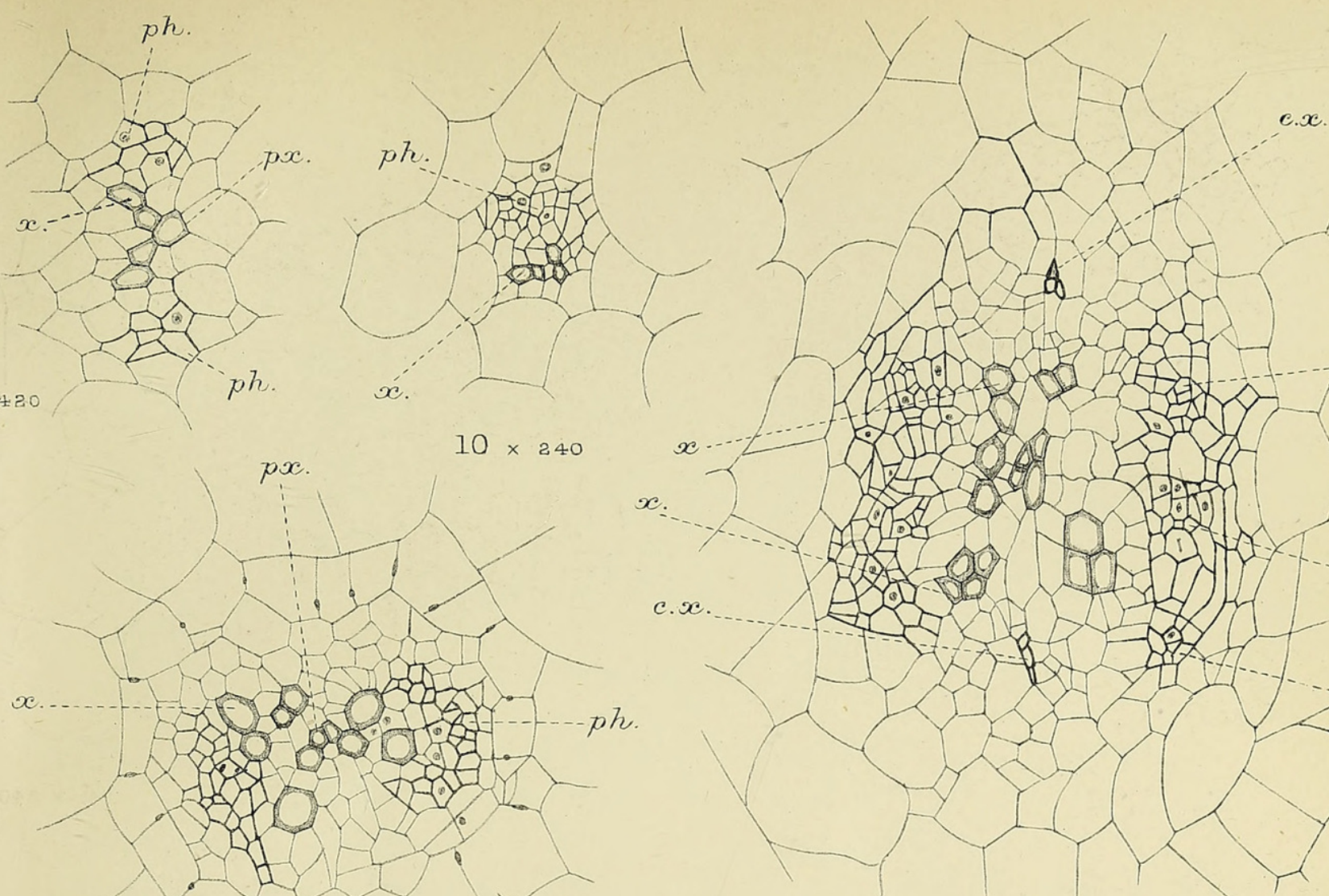

$$
\text { ènd. ph. } 11 \times 240
$$

$12 \times 240$
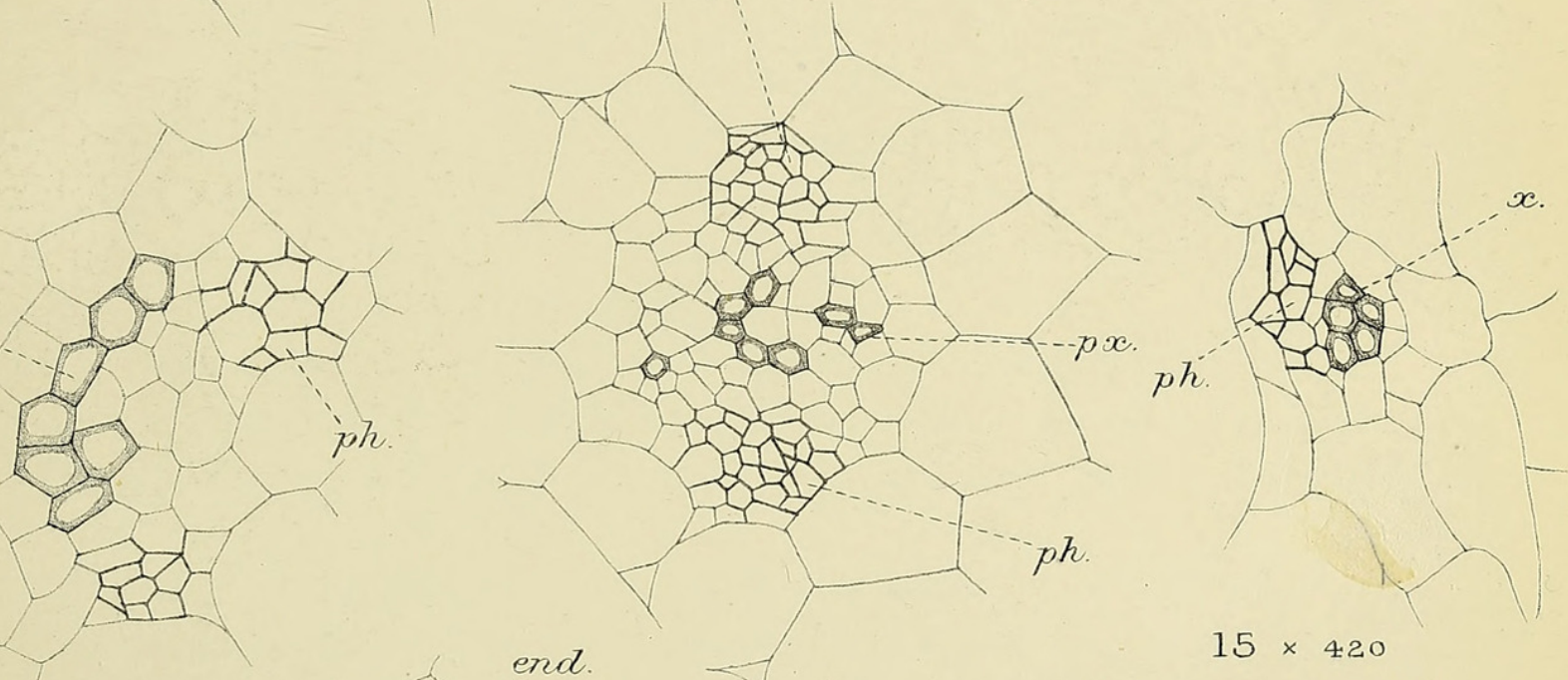

$13 \times 420$

$14 \times 240$

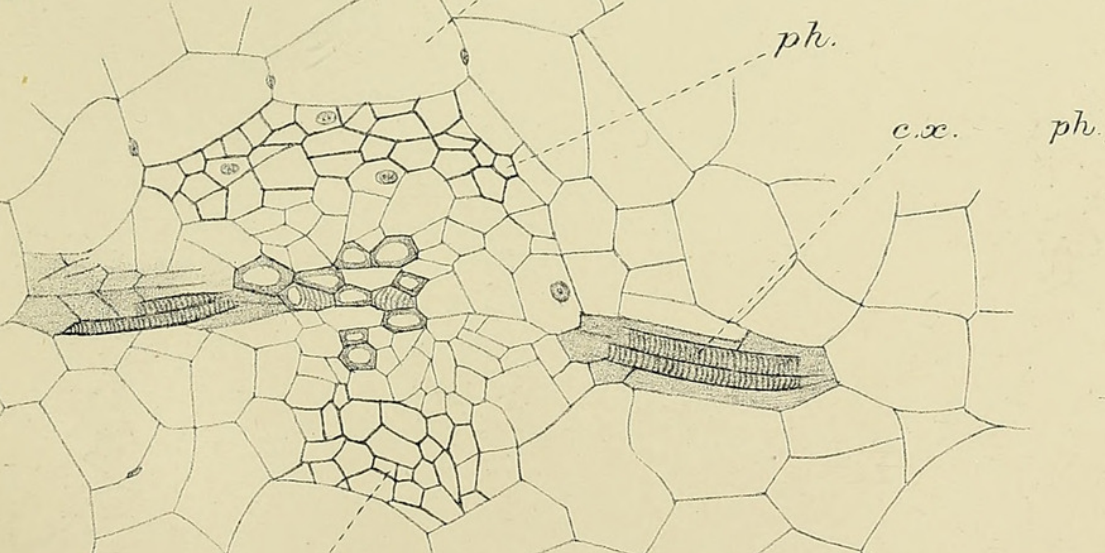

end 


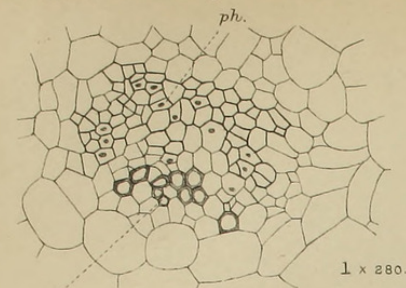

$p x$

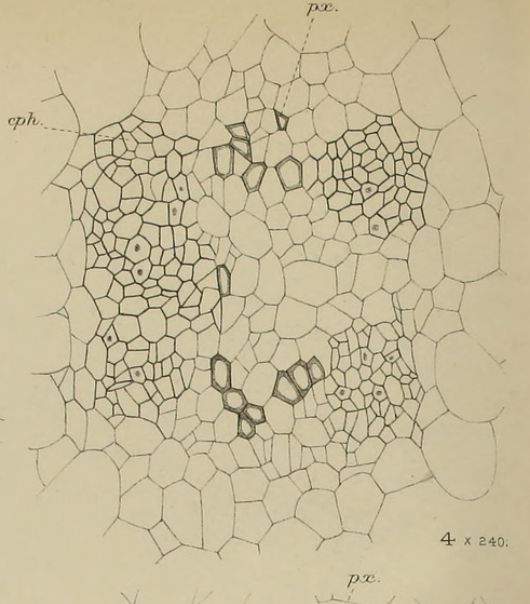

ph

ph

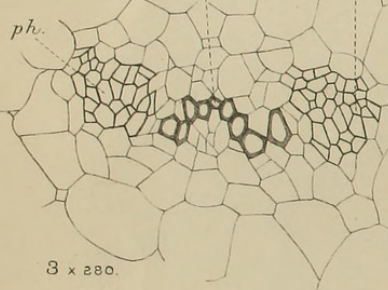

px.

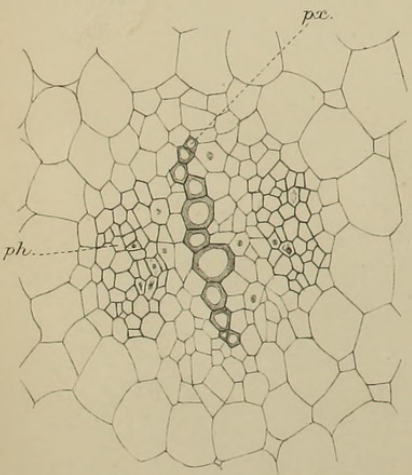

$6 \times 840$
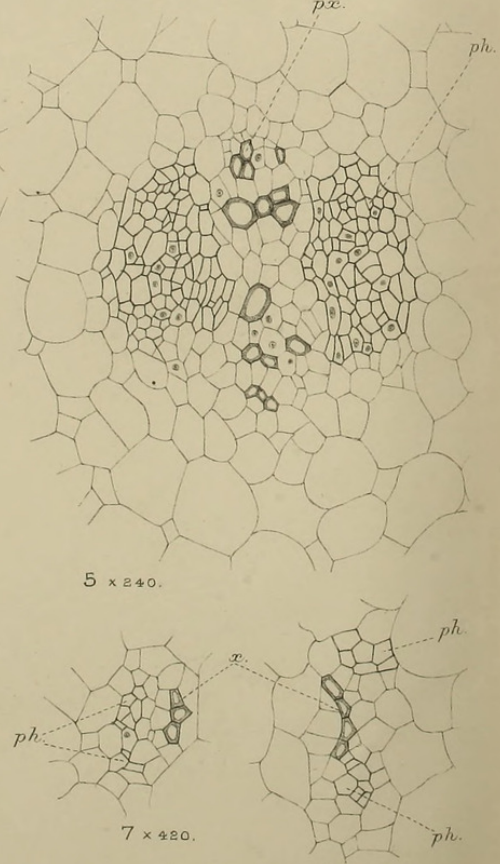

$8 \times 420$.
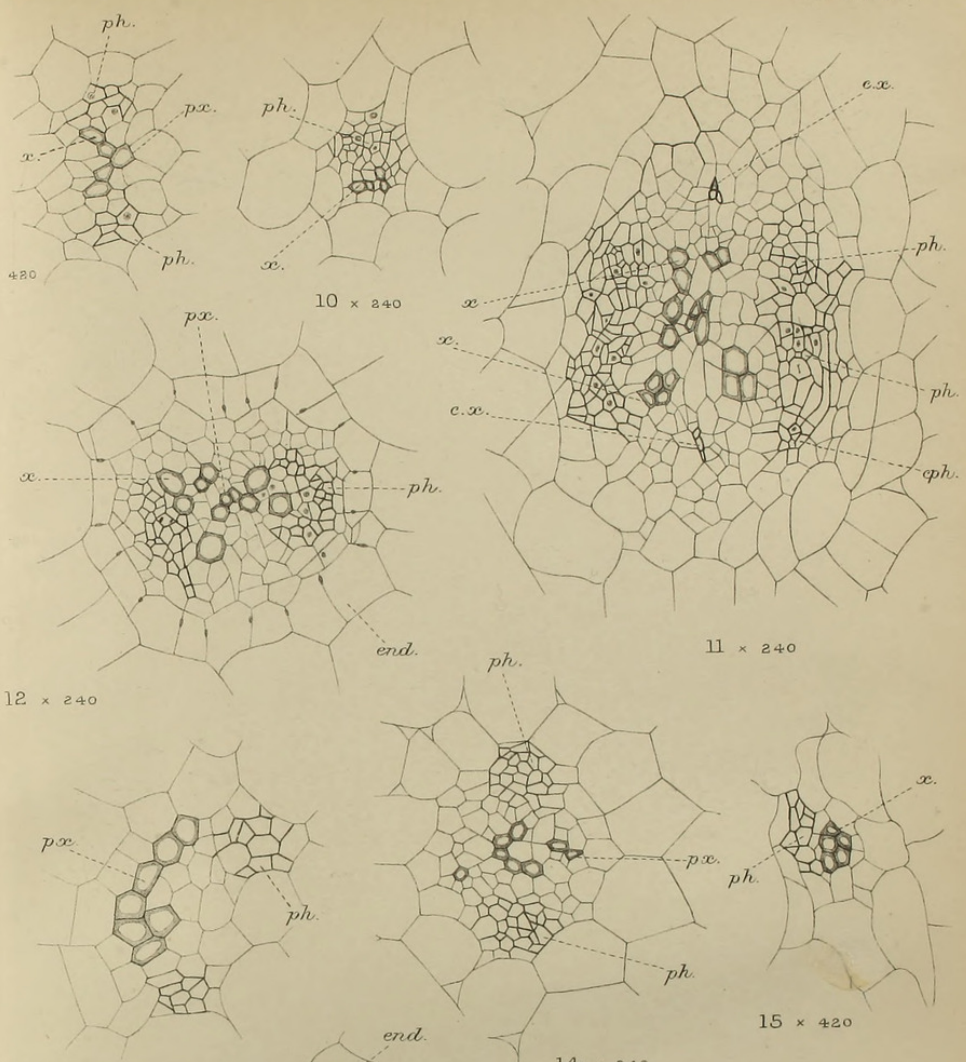

$11 \times 240$

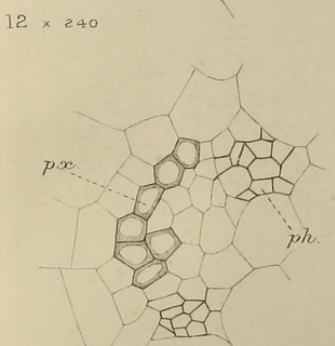

$14 \times 240$

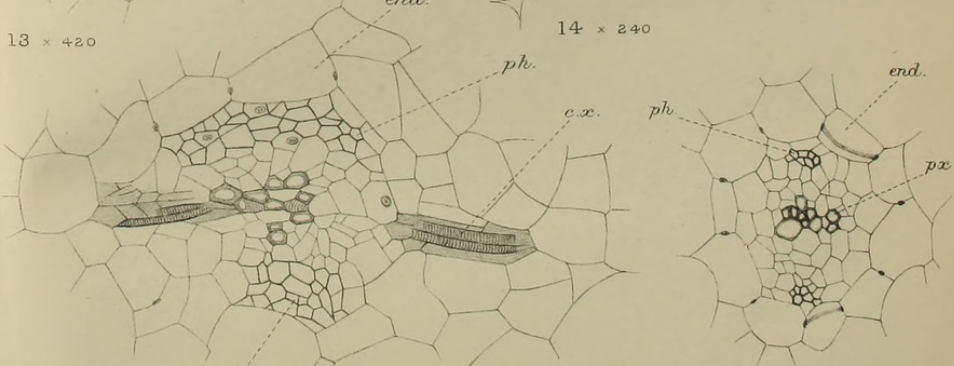

$16 \times 240 \quad p h$

$17 \times 240$

Huth, lith ot imp. 


\section{$2 \mathrm{BHL}$ Biodiversity Heritage Library}

Hill, T. G. 1906. "On the seedling-structure of certain Piperales." Annals of botany 20, 161-175. https://doi.org/10.1093/oxfordjournals.aob.a089089.

View This Item Online: https://www.biodiversitylibrary.org/item/234848

DOI: https://doi.org/10.1093/oxfordjournals.aob.a089089

Permalink: https://www.biodiversitylibrary.org/partpdf/318829

\section{Holding Institution}

Smithsonian Libraries

\section{Sponsored by}

Biodiversity Heritage Library

\section{Copyright \& Reuse}

Copyright Status: Not in copyright. The BHL knows of no copyright restrictions on this item.

This document was created from content at the Biodiversity Heritage Library, the world's largest open access digital library for biodiversity literature and archives. Visit BHL at https://www.biodiversitylibrary.org. 